\title{
MACROFAUNA COMPOSITION OF TWO BEACHES WITH DISTINCT MORPHODYNAMISM DEGREES IN THE BEACH ARC BARRA DE SÃO JOÃO - PONTA DO PAI VITORIO PROMONTORY - RJ.
}

\author{
ANDRADE, F.C.*; MASSUD-RIBEIRO, R.J. \& VELOSO, V.G. (in memoriam) \\ Laboratório de Ecologia Bêntica (Departamento de Ecologia e Recursos Marinhos) - Universidade \\ Federal do Estado do Rio de Janeiro, RJ, Brasil. \\ ${ }^{*}$ Corresponding author: fernanda.andrade@ymail.com
}

\begin{abstract}
Andrade, F.C.; Massud-Ribeiro, R.J. \& Veloso, V.G., (2016). Macrofauna composition of two beaches with distinct morphodynamism degrees in the beach arc barra de São João - Ponta do Pai Vitorio Promontory - RJ. Braz. J. Aquat. Sci. Technol. 20(1). elSSN 1983-9057. DOI: 10.14210/bjast.v20n1. This study was performed in the intertidal zone of Rasa and Unamar beach, located in the beach arc Barra de São João - Ponta do Pai Vitório Promontory, northern coastline of Rio de Janeiro, a poorly studied area. In order to assess the macrofauna composition samplings were carried out at both beaches on winter of 2003 (June, July e August) and summer of 2004 (December, January e February). The differences between the beaches are significant regarding both morphodynamic and macrofaunal composition. The Unamar beach is narrow and has a steeper slope, where waves reach directly the foreshore, being classified as reflective with a typical fauna of this morphodynamic stage, where crustaceans were the dominant taxon represented by Emerita brasiliensis, Excirolana braziliensis, Atlantorchestoidea brasiliensis and Lepidopa richmondi. Rasa beach, on the other hand, has a larger width with a gentle slope and an extense surf zone, classified as dissipative, with Dean's Morphodynamic index $(\Omega)$ equal to 5,1 and 8,5 respectively on winter and summer. The fauna is richer and extremely distinct from other beaches in Rio de Janeiro state, presenting unique species, as Talorchestia tucurauna, Platorchestia monodi, Aspidosiphon (Aspidosiphon) muelleri and Austinixa patagoniensis. This sipunculid as well the coleopteran Bledius hermani also found at this beach represents the first occurrence to Rio de Janeiro
\end{abstract}

Keywords: Sandy beaches, Macrofauna composition, Morphodynamic stages, Northern Rio de Janeiro coast.

\section{INTRODUCTION}

The morphology and dynamic of sandy beaches are resulted from wave energy, tide amplitude, wind action, grain size, slope and swash climate. The interaction among these factors is known as morphodynamic. Each of those parameters has wide timeline variation which generates morphodynamics gradients, being reflective beaches with coarse sand, steep slope and a narrow surf zone at one extreme and dissipative beaches with fine sand, a gentle slope and wide surf zone at the other (Short \& Wright, 1983).

The morphodynamic characterization of oceanic exposed sandy beaches has been carried out based on several indexes which have taken into account the parameters wave height and period, grain size, tide range and beach profile (McLachlan \& Dorvlo, 2005). The ecology of sandy beaches are being subject of study of numerous authors in the last decades, in which the morphodynamic differences, mainly in sediment budget, as a consequence of coastal processes can influence on the macrofauna (Jaramillo \& McLachlan, 1993; Jaramillo, 1994; Souza \& Gianuca, 1995; Borzone et al., 1996; Borzone \& Souza, 1997; Jaramillo et al., 2001; Veloso \& Cardoso, 2001; Borzone et al., 2003; Veloso et al., 2003; Defeo \& McLachlan, 2005; Rodil et al., 2007). Based on those studies and many others several patterns have been identified. Generally, they reported that on beaches with coarser sand and short swash period are more "severe" leading to the exclusion of some species (McLachlan, 2001). On the other hand, beaches with fine sand that accumulates large quantities of water and organic matter support communities of greater richness, abundance and biomass (McLachlan, 1990; McLachlan et al., 1993).

Numerous studies had analyzed the relation among the macrofauna descriptors and physical factors along the gradient reflective - dissipative in beaches at different locations (McArdle \& McLachlan, 1992; Barros, 2001; Brazeiro, 2001; Veloso et al., 2001; Lastra, 2006;). However, it is uncommon studies both on physical or biological characteristics on morphodynamic extremes on the same beach arc. Since beaches features are resulted of a series of geological, oceanographic and climatic processes which act in the coastal zone in different scale of time (Short, 1999), it is possible to observe along a beach arc different morphodynamic stages. In addition, climatic processes as precipitation, winds and geomorphologic features as rivers, headland rocks and islands must be taken into account in order to understand the local morphodynamic. These processes combined with the local geomorphology can generate massive differences between beaches, but also along a beach arc, since 
it will impact directly on refraction and diffraction of waves and consequently on composition and mobility of the sediment budget (Short, 1996). The existence of rivers flows is a factor of remarkably importance, not only as a sediment supplier of fine sand for the beach ecosystem, but also for leading to the sector under influence aspects of dissipative stage, meaning low mobility and flat profile (Figueiredo \& Calliari, 2006).

In this context, the present contribution represents a description of macrofauna on a reflective and a dissipative beach inside the beach arc Barra de São João - Ponta do Pai Vitório promontory. This beach arc has peculiar geomorphologic aspect throughout its $14 \mathrm{~km}$ of extension, since it is divided into two distinct segments. To the north, the arc is classified as reflective, whereas to the south all the dissipative characteristics occur. These differences are related to geological inheritance, rivers inputs also currents generate locally (Fernandez \& Muehe, 1998; Andrade et al., 2010). From the geomorphologic point of view the northern of Rio de Janeiro coast has been broadly studied, but there are few studies regarding the ecology of sandy beaches. So, this study aims to evaluate the macrofauna composition of two sandy beaches with distinct morphodynamism degrees.

\section{MATERIAL AND METHODS}

\section{Study Area}

The study area is localized in the northern coastline of Rio de Janeiro, precisely between the town of Barra de São João and Ponta do Pai Vitório promontory, part of the wide embayment between Rio das Ostras and Búzios cape (Muehe et al.,2006).

The studied beach arc is divided into two segments with distinct morpho - sedimentary aspects, result from a series of combined elements, such as: various degrees of wave exposure, rivers outlets, sediment transport also currents. On this arc are the watersheds of São João, Ostras and Una rivers, being the first one the main river (Fernandez, 1998). The São João River is the main sediment supplier for the continental shelf and its further use to build coastal plains, whereas the watershed of Una and Ostras rivers due to its low volume inputs are less significant (Fernandez, op. cit.). Accordingly, as a result of fine sediment accumulation from the rivers added to the protection from Buzios cape, in Rasa beach all the dissipative characteristics occur, on the other hand in Unamar due to ample wave exposition is observed a reflective beach.

\section{Sampling and Laboratory Procedures}

Two beaches along the beach arc were selected for this study. To the south is Rasa beach $\left(22^{\circ} 43^{\prime} 24,73^{\prime \prime}\right.$ $\left.\mathrm{S} 41^{\circ} 58^{\prime} 53,35^{\prime \prime} \mathrm{W}\right)$, approximately $1 \mathrm{~km}$ from Una river and $14 \mathrm{~km}$ from São João river. Toward to north is Unamar beach, away $1,14 \mathrm{~km}$ from São João river

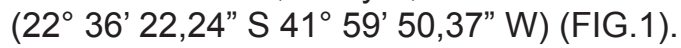

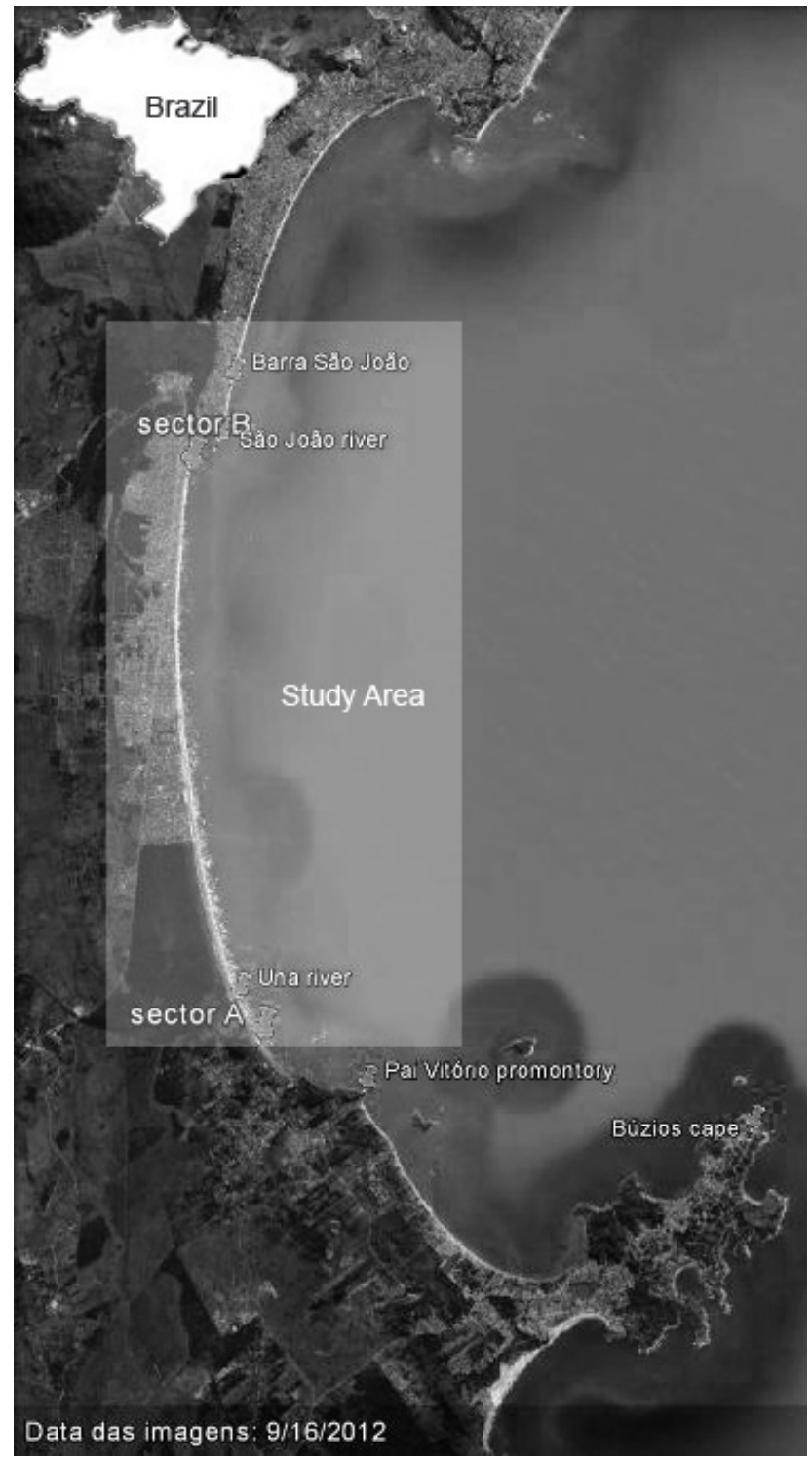

Figure 1 - Map of the beach arc Barra de São João - Ponta Pai Vitório Promontory, northern of Rio de Janeiro, showing the locations of the studied beaches. Unamar at north and Rasa beach at south.

Both physical and biological samplings were carried out on winter of 2003 (June, July, and August) and summer of 2004 (December, January and February). On each beach six transects were established from the lower limit of the swash zone to the drift line, and ten equally spaced sampling strata were marked. At each stratum one sample was taken with a $0,04 \mathrm{~m} 2$ (3 m apart) quadrat to a depth of $15 \mathrm{~cm}$. 
The collected material was washed, in the field, through a $0,05 \mathrm{~mm}$ sieve, and the retained material was taken to the laboratory, where the organisms were sorted out by species, counted and fixed $5 \%$ formaldehyde. In addition to the quadrats, a qualitative sampling was carried out for ghost crabs, Ocypode quadrata (Fabricius, 1787) and Callichrus major (Say, 1818). The former, an area of $10 \mathrm{~m} 2$ was established where the number of organisms was estimated through the counting of burrows. For the latter five samples were collected using a suction pump in the three last levels near the waterline. These qualitative data were only used to characterize the faunistic composition of the beaches and were no included in the statistical analysis.

For the physical characterization, on each beach, the beach profile was measured by the height difference (Emery, 1961) between the drift line and the water line. Sediment samples for particle size were taken with a corer of $3,5 \mathrm{~cm}$ diameter to a depth of $10 \mathrm{~cm}$ at each stratum. In addition measures of wave height $(\mathrm{Hb})$, period $(\mathrm{T})$ and swash period (Tswash) were taken (Muehe, 1996). The morphodynamic characterization was done calculating Dean's dimensionless parameter $(\Omega)$.

Sediment samples were over dried at $70^{\circ} \mathrm{C}$ and passed through a series of sieves of 0.5 phy intervals in order to determine mean particle size (Suguio, 1973). Results were expressed in $\mathrm{mm}$. Mean and standard desviation were computed according to Folk \& Ward (1957). The humidity of sediment was measured through the differences of weight before and after over dried at $70^{\circ} \mathrm{C}$ The organic content of sediment was estimated throw the loss of weight after ashing $5 \mathrm{~g}$ of sediment at $600^{\circ} \mathrm{C}$ for six hours (Conceição et al., 1999).

\section{Statistical Analysis}

For the biological analysis, first the liner meter abundance (ind $/ \mathrm{m}$ ) for each organism and stratum was calculated. This abundance integrates square meters abundance data from each stratum with the distance between the stratums.

A non-parametric permutational multivariate analysis of variance (PERMANOVA) was conducted so as to verify the macrofauna variation between the beaches and season (winter and summer). This analysis used Bray - Curtis similarity calculated from the abundance matrix of macrofauna $[\log (x+1)$ transformed]. It was also executed a principal components analysis (PCA) with the abiotic factors: wave height, wave period, swash period, slope, mean particle size, sorting, curtosis, $\%$ organic matter and $\%$ humidity.

\section{RESULTS}

\section{The Beaches}

The two beaches sampled in the beach arc between the town of Barra de São João and Ponta do Pai Vitório Promontory showed distinctive morphodynamic and sedimentological characteristics. Rasa beach was characterized as dissipative and Unamar as reflective on both seasons. Despite not having occurred variations in Dean's morphodynamic index, it was verified differences in the slope and beach lenght. Slope values showed that Rasa beach is extremely plan (Fig.2), meanwhile at Unamar the slope is abrupt. The beach length at Rasa varied between the months sampled, in which the highest value was observed in December and the smallest in August. However, at Unamar the length was not greater than 20 meters, whose the smallest length was observed in June (Fig.2).

The sediment was composed of fine sand at Rasa beach and coarse sand was found in Unamar (Tab.2). At Rasa was also verified a well sorted sediment and leptocurtic, while in Unamar the sediment varied between moderate to moderate well sorted and the kurtosis was characterized as mesocurtic (Tab.2). In the dissipative beach the values of organic matter and humidity were greater than on the reflective (Tab.2).

Table 1 - Morphometric parameters of the studied beaches. Summer and winter data are expressed as mean values. $\mathrm{Hb}$, $\mathrm{T}_{\text {and }} \mathrm{T}_{\text {swash }}$ means respectively wave height, wave period and swash period.

\begin{tabular}{ccccccccccc}
\hline & \multicolumn{2}{c}{ Dean's } & \multicolumn{2}{c}{ Hb (cm) } & \multicolumn{2}{c}{ T (s) } & \multicolumn{2}{c}{ Tswash $_{\text {swa }}$} & \multicolumn{2}{c}{ Slope (1/x) } \\
\hline \multirow{3}{*}{ parameter } & Win & Sum & Win & Sum & Win & Sum & Win & Sum & Win & Sum \\
Rnamar & 5,09 & 8,5 & 84,3 & 51,5 & 9,7 & 9,6 & 15,5 & 11,6 & 36,8 & 38 \\
& 0,8 & 0,75 & 101,8 & 114,2 & 11,1 & 9,5 & 4,5 & 4,2 & 5,6 & 7,3 \\
\hline
\end{tabular}

Table 2 - Sedimentological parameters of the studied beaches. Summer and winter data are expressed as mean values.

\begin{tabular}{ccccccccccc}
\hline & \multicolumn{2}{c}{ Grain size (mm) } & \multicolumn{2}{c}{ Humidity (\%) } & \multicolumn{2}{c}{$\begin{array}{c}\text { Organic matter } \\
(\mathbf{\%})\end{array}$} & \multicolumn{2}{c}{ Sorting } & \multicolumn{2}{c}{ Curtosis } \\
\hline \multirow{3}{*}{ Rasa } & Win & Sum & Win & Sum & Win & Sum & Win & Sum & Win & Sum \\
Unamar & 0,14 & 0,12 & 24,9 & 21,7 & 3,3 & 4,4 & 0,49 & 0,34 & 1,48 & 1,2 \\
\hline
\end{tabular}



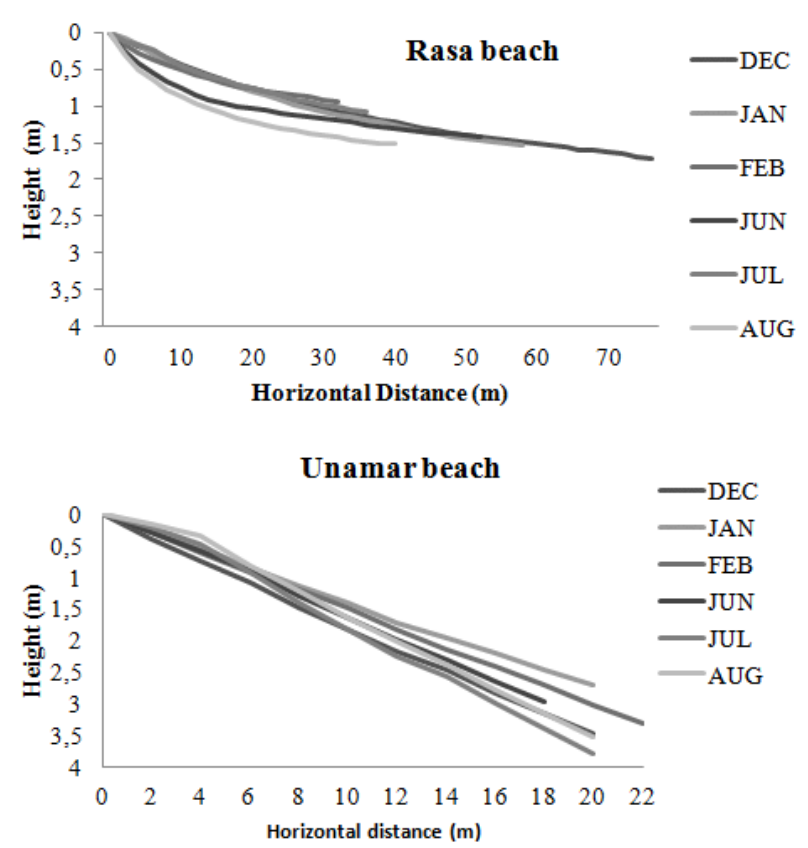

Figure 2 - Diagram of the beach profiles at Rasa and Unamar.

\section{The Macrofauna}

It was observed 24 and 19 species at Rasa beach, while at Unamar occurred only 10 and 11 species, respectively in winter and summer. The species Excirolana braziliensis (Richardson, 1912), Olivancillaria vesica (Gmelin, 1791) and Scolelepis (Scolelepis) squamata (Muller, 1806) were the only ones in common at both beaches (Tab. 3). At Rasa beach the Mollusca group showed higher richness in winter. The Crustacean group did not show richness variation in the seasons at both beaches, being observed seven and five species respectively at Rasa and Unamar beach. At Unamar it was verified two species of Mollusca and Polichaeta on both seasons (Tab.3). The greater values of abundance were verified at Unamar in winter and at Rasa in summer. At both beaches the Crustacean group contributed with the higher abundance values. In spite of the higher richness of Mollusca group at Rasa, its abundance was not very high, being observed $354 \mathrm{ind} / \mathrm{m}$ and $258,2 \mathrm{ind} / \mathrm{m}$, respectively in winter and summer. Polichaetas showed high abundance values in winter at both beaches (Tab.3).

The Rasa beach, localized in the south, showed higher abundance of Crustaceans in summer and winter. The isopods from Cirolanidae family, Excirolana braziliensis and Excirolana armata (Dana, 1853), the amphipodas from talitridade family Platorchestia monodi (Stock, 1996) and phoxocephalopsidae family Puelche sp. (Bernard \& Clark, 1982) were the most abundant among this group, having been most expressive in summer (Tab.3). It was also observed the amphipodaTalorchestia tucurauna (Muller, 1894), but in lesser abundance. Among Mollusca, the most abundant was the gastropod Olivella minuta (Link, 1807). Donax gemmula (Morrinson, 1971) another bivalve common in dissipative beaches was registered at Rasa with abundance values equal to 34,1 and 51,5 respectively in winter and summer. The Polychaeta Hemipodia californiensis (Hartman, 1938) was the most abundant, followed by Dispio remanei (Friedrich, 1956) both in winter. The Sipunculid Aspidosiphon (Aspidosiphon) muelleri (Diesing, 1851) was observed only at Rasa beach with higher abundance values in winter and summer. The insect group was represented by the Coleoptera Staphylenidae, Bledius hermani (Caron \& Ribeiro - Costa, 2007), the first record in Rio de Janeiro State. The values of abundance were equal $346,08 \mathrm{ind} / \mathrm{m}$ and $455,24 \mathrm{ind} / \mathrm{m}$, respectively in winter and summer. The density of the decapod Callichrus major varied from $32 \mathrm{ind} / \mathrm{m} 2 \mathrm{in}$ winter to $43 \mathrm{ind} / \mathrm{m} 2$ in

Table 3 - Mean values of abundance (ind $/ \mathrm{m}$ ) per species, total abundace and richness for each beach, winter and summer. Density (ind/m2) for Callichirus major and Ocypodequadrata in winter and summer.

\begin{tabular}{|c|c|c|c|c|}
\hline Species & $\begin{array}{c}\text { Rasa } \\
\text { Winter }\end{array}$ & $\begin{array}{c}\text { Rasa } \\
\text { Summer }\end{array}$ & $\begin{array}{l}\text { Unamar } \\
\text { Winter }\end{array}$ & $\begin{array}{l}\text { Unamar } \\
\text { Summer }\end{array}$ \\
\hline Costoanachis sertulariarum & 43,9 & & & \\
\hline Armandia agilis & 79,1 & & & \\
\hline Aspidosiphon (Aspidosiphon) mulleri & 784 & 1734,1 & & \\
\hline Atlantorchestoidea brasiliensis & & & 40 & 126,5 \\
\hline Austinixa patagoniensis & 192 & 277 & & \\
\hline Bledius hermani & 346,1 & 455,2 & & \\
\hline Dispio remanei & 325,8 & 10,8 & & \\
\hline Donax gemmula & 34,1 & 51,5 & & \\
\hline Donax hanleyanus & & & 70 & 187 \\
\hline Emerita brasiliensis & & & 6585 & 2100 \\
\hline Epitonium humphresyii & 29,8 & 35,6 & & \\
\hline Excirolana armata & 424,1 & 818,1 & & \\
\hline Excirolana braziliensis & 300,5 & 979,7 & 380 & 957 \\
\hline Hemipodia sp. & & & 25,0 & 170,5 \\
\hline Hemipodia californiensis & 603,8 & 176,2 & & \\
\hline Larva Diptera & & & & 11 \\
\hline Lepidopa richmondi & & & 160,4 & 25 \\
\hline Nucula puelcha & 32,5 & & & \\
\hline Olivancillaria vesica & 50 & 28,8 & 18,3 & 8,3 \\
\hline Olivella minuta & 77,3 & 113,6 & & \\
\hline Phaleria testacea & & & 20 & 11 \\
\hline Pholas campechiensis & 39,4 & 28,8 & & \\
\hline Platorchestia monodi & 247,5 & 604,6 & & \\
\hline Puelche sp. & 227 & 193,9 & & \\
\hline Scolelepis (Scolelepis) squamata & 53,5 & 158,2 & 1595 & 145,8 \\
\hline Scoloplos sp. & 193,8 & 103,5 & & \\
\hline Sigalion taquari & 36,8 & 61,1 & & \\
\hline Talorchestia tucurauna & 39,9 & 17,8 & & \\
\hline Tegula viridula & 40,9 & & & \\
\hline Terebra riosi & 45,5 & & & \\
\hline Total Abundance (ind/m) & 4247 & 5849 & 8894 & 3742 \\
\hline Total Richness & 24 & 19 & 10 & 11 \\
\hline Callichirus major (ind $/ \mathrm{m}^{2}$ ) & 32,0 & 43,0 & & \\
\hline Ocypode quadrata (ind $/ \mathrm{m}^{2}$ ) & & & 1,8 & 3,3 \\
\hline
\end{tabular}

summer (Tab.3).

At Unamar, Crustaceans were the most abundant, represent by Emerita brasiliensis (Schmitt, 
1935) and Excirolana braziliensis. The abundance of the former one was $6585 \mathrm{ind} / \mathrm{m}$ only in winter (Tab. 3).Among the Mollusca group, the bivalve Donax hanleyanus (Philippi, 1842)showed higher abundance in summer. The gastropod Olivancillaria vesica also occurred at Unamar, but the abundance values were not high. In relation to Polychaeta group,Scolelepis (Scolelepis) squamata was abundant in winter. It was also register high abundance of Hemipodia sp. in summer. The ghost crab (Ocypode quadrata) observed only at this beach, where its densities varied from $1,8 \mathrm{ind} / \mathrm{m} 2$ in winter to $3,3 \mathrm{ind} / \mathrm{m} 2$ in summer (Tab.3).

The PERMANOVA analysis for two factors (beach and season) revealed significant differences in macrofauna between the factors $(p<0,05)(T a b .4)$.

Table 4 - PERMANOVA on Bray Curtis similarity for macrofauna for the factors: period, beaches also interaction between beaches and period.

\begin{tabular}{lrrrr}
\hline & df & \multicolumn{1}{c}{ MS } & F & p \\
\hline beach & 1 & 27412 & 12,9 & 0 \\
Períod & 1 & 4475 & 2,11 & 0,02 \\
Beach * & & & & \\
Períod & 1 & 5509,8 & 2,59 & 0 \\
Error & 20 & 2124,6 & & \\
\hline
\end{tabular}

The principal components analysis (PCA) showed that $91,92 \%$ of the variance was explained by the first two axes. The first axis explained $81,09 \%$ from the total variance, while the second axi explained only $10,83 \%$ from the variance. The using of PCA made clear the differences between the two beaches and seasons. The Rasa beach, in the summer and winter, was plotted in the negative region of the first axis, being better explained by the higher values of organic matter, humidity also sorting and grain size (Fig.3). The Unamar beach, on both seasons, was plotted in the positive region of the first axis. This beach, in the winter, was better explained by the swash period and slope,

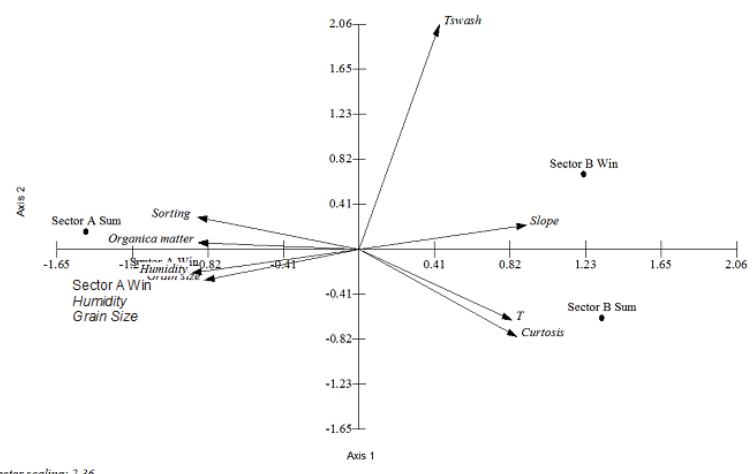

Figure 3 - Principal Components Analysis (PCA) - The first axi $(81,09 \%$ variance) and the second axi $(10,83 \%$ variance). The circles represent the beaches (Sector A - Rasa beach and Sector $\mathrm{B}$ - Unamar beach) and the arrows are the physical parameters ( $T$ - wave period and Tswash-Swash period). while the factors wave period and curtosis explained better Unamar in summer (Fig.3).

\section{DISCUSSION}

\section{The beaches}

The measurement of topographic profiles, estimates of oceanographic and sedimentological parameters on the beach arc between the town of Barra de São João and Ponta do Pai Vitório promontory made feasible to confirm that the arc actually behaves as two distinct beaches, corroborating with others studies carried out in the region (Bentes et al., 1997; Fernandez \& Muehe, 1998; Andrade et al., 2010). Those differences are directly related to the inputs from Ostras, São João and Una rivers, also local currents plus the geological inherence from the area. According to Moriak \& Barros (1990), between Macaé and Búzios there is an asymmetric graben, which means, a depression of tectonic origin. Generally, it has the form of a long valley with plan bottom, formed when a block of territory sank in relation to the surrounding territory as a result of combined movements of geologic parallels and semi parallels faults. This small sedimentary basin makes favorable the sediment deposition, although other factors like local currents added to wave action favor the fine sediment to accumulate in the south, generating sedimentological characteristics far distinct from the north of the beach arc (Fernandez \&Muehe, 1998).

At Rasa beach the accumulation of fine and very fine sediment, mainly from São João river in the north, but also from Una river, is favored by the fair weather waves from the northeast. Those waves generate current from north to south, carrying along the coast fine sediment to south. Added to that, the existence of Cape Buzios, to the south, avoids storm waves from southeast acting in the region, which creates an area of low hydrodynamism where there is not much alteration of sediment budget and the profile remains flat (Fernandez \& Muehe, 1998). The influence of sediment from rivers was also verified by Figueiredo \& Calliari (2006) in the southern coast of Brazil. Those authors had demonstrated that the fine sediment from Patos Lagoon contributed for the dissipative characteristics observed in Mar Grosso and Querência beaches, which have shown few variation on volume and mobility of sediment budget.

On the other hand, Unamar beach is reached by storm waves coming from southeast, which generate an intense hydrodynamics in the intertidal region avoiding the deposition of fine sediment. The absence of a protection from waves creates a beach profile extremely short and steep. A study carried out in the area by Andradeet et al. (2010) about morphodynamic and sedimentology verified that at this beach occur highly mobility of beach profile, also the predominance 
of coarse and medium sand corroborating to what was observed in this paper.

From the geomorphologic approach, this beach arc has already been studied by systematic measurement of topographic profile along with sedimentological analysis (Fernandez \&Muehe, 1998; Andrade et al., 2010). Those papers showed that the fine sediment, especially from São João River, leads to a plain shoreface toward to the south. Accordingly, the beach arc becomes dissipative to ultradissipative as the grain size becomes finer and the wave exposure decreases due to Búzios cape protection. Meanwhile, the opposite is verified to north of the beach arc, where coarse sand prevails since it is observed total wave exposure.

\section{The Macrofauna}

Both beaches are formed by a very distinct fauna, where few species occur in common. The presence of Excirolana braziliensis, Olivancillaria vesica and Scolelepis (Scolelepis) squamataat both morphodynamic extremes shows a fact already confirm in many studies, that some species of beach macrofauna have a high physiological plasticity being able to live in different types of beaches (Veloso et al., 2003; Fernandes \& Gomes, 2006; Veloso et al., 2006).

The richness at Rasa beach was higher in summer and winter, when compared to Unamar. Various studies showed that in dissipative beaches, less harsh conditions such as intense hydrodynamic confined to the surf zone, less harsh swash climate, a more stable substrate and a higher quantity of organic matter allows a greater number of species (McLachlan et al., 1993). While in Unamar the breaking wave directly on the foreshore, in addition to the coarse sand causes subsequently lesser swash period and water retention. Those reflective conditions are pointed out as severe for most of the individuals of macrofauna, leading to a small number of species adapted to such harsh environmental conditions (Defeo \& McLachlan, 2005).

The Rasa beach, despite showing higher richness the abundance of each species was not very high. Some of observed species had already been verified on dissipative beaches at Rio de Janeiro and Parana state, such as Hemipodia californiensis, Austinixa patagoniensis, Platorchestia monodi, Excirolana armata, Excirolana braziliensis, Donax gemmula and the gender Puelche. The H.californiesis and A. patagoniensis occurred in elevated abundance in dissipative and intermediate beaches at Superaguii National Park (Martins, 2007). The Amphipod Platorchestia monodi was also verified in dissipative beaches of the mentioned Park. This Amphipod is one of the three terrestrial species that occur along south and southeast Brazil coastline (Serejo, 2004). P. monodi had already been reported on sandy beaches at Paranagua bay, and according to the authors this specie prefer protect and estuarine beaches (Rosa et al.,2007). The presence of this specie at Rasa beach can be related to the hydrodynamic conditions from it which can be similar to the characteristics observed at some protected beaches, such as low variation of the profile and more stable substrate. The gender Puelche had already been observed at Atami, a dissipative beach at Parana state (Borzone \& Souza, 1997). Excirolana armata, Excirolana braziliensis and Donax gemmula besides being observed in dissipative beaches in Rio de Janeiro, Parana and Rio Grande do Sul states (Souza \& Glianuca, 1995; Borzone \& Souza, op.cit.; Fernandes \& Gomes, 2006; Neves \& Bemvenuti, 2006; Martins, 2007) were also verified in high abundance on protected sandy beaches with fine grain, like those in Caraguatatuba coast and Sepetiva Bay (Loureiro, 2006; Amaral et al., 2011). Those protected beaches have characteristics very similar to the ones observed in dissipative beaches, such as wide and plan profile combined with fine sediment. The gastropod Olivella minuta frequent at Rasa beach had not been registered on exposed sandy beaches only in protected ones (Loureiro op.cit.; Amaral op.cit.).

The Sipunculid Aspidosiphon (Aspidosiphon) mulleri observed at Rasa beach can be found in a single form or associated to empty shelves in the lower zone, being few the records of it in sandy beaches. The occurrence of this specie at Rasa is possibly related to it's peculiar characteristics, as the very fine and compact sediment, large swash zone and high quantity of humidity and organic matter.

At Unamar beach, the most representative species were the crustaceans Emerita brasiliensis, Lepidopa richmondi (Benedict, 1903), the Isopoda Excirolana braziliensis, E. armata and the Amphipoda Atlantorchestoidea brasiliensis, all of them common and frequent on reflective and intermediate beaches of Rio de Janeiro coastline (Veloso \& Cardoso, 2001; Veloso et al., 2003; Veloso et al., 2006). In general Crustacean are well succeeded in such severe conditions, showing high mobility and tolerating environments with low humidity (Schlander et al., 2008). Despite the low richness of reflective beaches, some species can occur on higher abundance as observed on this paper for Emerita brasiliensis, Excirolana braziliensis (Defeo et al., 2001; Fernandes \& Soares - Gomes, 2006).

At Rasa beach besides the dissipative conditions which allows the establishing of a greater number of species, is also observed the influence of a large amount of marine macrophyte wrack which is deposited on it. The Amphipoda Talorchestia tucurauna found only at this beach is common and abundant in those deposited materials. This specie was observed at 
beaches intermediate and dissipative at Parana state, however T.tucurauna was not verified in significant abundance in the dissipative beaches (Martins 2007). This point out how this specie might be highly related to the deposited material and its low abundance on the present study can be explained by sampling methodology, since the main objective was not the drifted material. At Rasa beach this material is composed by Sargassum furcatum (Kutzing, 1843), Osmundaria obtusiloba (Norris,1991), Salvinia sp. and Typha domingensis, which appears in high biomass (Capper, 2011). The influence of these marine macrophytes inputs on beach diversity has been discussed recently, showing a specific macrofauna associated with this material and using it as food resource and shelter (Brown \& McLachlan, 1990; Dungan et al., 2003).

Some species occurred on both beaches, the Isopoda Excirolana braziliensis was one of them. This specie is common and frequent on reflective medium to coarse sandy beaches of south and southeast Brazil coastline (Borzone et al., 1996; Barros et al., 2001; Veloso \& Cardoso, 2001). The other species of this gender, Excirolana armata, found only in Rasa beach, is frequently observed in shelter beaches of bays and exposed dissipative beaches with fine sand, not being observed on reflective beaches (Souza \& Gianuca, 1995; Borzone \& Souza, 1997; Borzone et al., 2003; Neves \& Bemvenuti, 2006). Defeo et al. (1997) have conducted laboratory and field experiments, and suggested that these differences on the occurrence of those species are related to humidity tolerance and grain size, being Excirolana braziliensis the one with high physiological plasticity. The co - occurrence of those species were also recorded on dissipative sandy beaches at Rio de Janeiro coastline (Fernandes \& Soares - Gomes, 2006).

The decapoda Challichirus major was characteristic from Rasa beach. This specie had already been studied at this exactly beach regarding its population structure (Simão et al., 2006). According to the authors this specie

is found on burrows on intertidal and sublitoral zone of dissipative beaches, also on protected beaches. At Rio de Janeiro this specie had already been observed in beaches at Sepetiba bay (Loureiro, 2006). The fine and mud sediment from those beaches make it easy to the construction of deep and stable galleries (Simão op.cit.). On those galleries it is very common to find a little crab from Pinnotheridae family, and at Rasa beach was found the specie Austinixa patagoniensis (Rathbun, 1918). This specie also occurred in Superaguii, a dissipative beach at Parana state (Martins, 2007). The knowledge about the ecology and biology of that specie is scarce, since most of the studies deal only with the presence of this orga- nism on the upper part of the galleries constructed by Callianassidae (Rodrigues \& Shimizu, 1997). Another specie characteristic from Rasa beach was the Coleoptera Bledius hermani found at the backshore region in high abundance. That specie was described by Caron \& Ribeiro - Costa (2007) for a sandy beach at Paraná, being the first record for a sandy beach in Rio de Janeiro state.

According to the principal components analysis it was verified that Rasa beach was better explained by the characteristics related to the sediment as grain size, organic content, humidity, while on Unamar were the hydrodinamic processes, such as swash and wave period. On the latter, the waves whose normally break on the foreshore leads to a sorting of grains moderately, so the coarse fractions predominates and subsequently low quantity of organic matter and humidity occur. On the other hand, on Rasa, the higher amount of organic matter, humidity, very common on beaches of fine and very fine sediment, in addition to the gentle profile, higher swash period and compacted sediment creates all the conditions to a fauna which builds burrows, galleries being richer and abundant.

Most of the beaches along Rio de Janeiro coastline are reflective or intermediate where some species are common with those one found in Unamar (Veloso et al., 2003). The species Emerita brasiliensis, Excirolana braziliensis and Atlantorchestoidea brasiliensis (Dana, 1853) observed in high abundance on this study were also verified in high abundance at Urca, Grumari, Barra da Tijuca, Itaipu, Itaipuaçú, Jaconé, Restinga da Marambaia, Massambaba, Pecado, Peró, Tucuns, Foguete, Formosa, Carapebus, Costa Azul, Boqueirão, Prainha and Fora beaches (Veloso et al., 2003; Fernandes \& Soares - Gomes, 2006). Those beaches are localized to the north of Rio de Janeiro coastline, since to the south the coastline is characterized by a barely developed coastline plains, narrow beaches limited by handlands (Muehe, 1998).

Regarding to dissipative beaches, the studies about macrofauna communities in Rio de Janeiro state occurred in few areas. However, the compilation of some ecology sandy beaches papers from southern and southeastern Brazil showed that Excirolana armata is the most frequent specie on this morphodynamic stage. Other species such as Scoleleps goodbodyi, Donax gemmula, Euzonus furciferus occurred in high abundance on dissipative beaches from Paraná and Rio Grande do Sul (Lepka, 2008). Another specie frequent observed in dissipative beaches at Parana and Rio Grande do Sul states is Donax hanleyanus which was verified on this study only at the reflective beach (Borzone \& Souza, 1997; Neves \& Bemvenuti, 2006).

Despite the study area being influenced by river mouths, the salinity parameter has not been 
taken into account, since the main goal of this paper was to describe the macrofauna communities of two beaches with mormorphodynamic differences. As described in many papers, sandy beaches are complex environment where physical factors like sand, tides, waves and beach face slope plays an important role, may prevail over, being responsible for community and population features (Defeo \& McLachlan, 2005; McLachlan \& Dorvlo, 2005).

Even though the sampling had taken place at only one sector at each beach, it was possible to describe the macrofauna of the morphodynamic extremes at the beach arc between the town of Barra de São João and Ponta do Pai Vitório Promontory. This study represents an important macrofauna characterization since it was developed in a region where there are not many sandy beaches ecology papers. It is worth mentioning that in Rio de Janeiro state there are few beaches with dissipative characteristics, therefore the present study represents an important ecological contribution for this morphodynamic stage. However, the data obtained from this study are sill insufficient to infer about community structure or spatial variations. It is clear the necessity of further studies in the area to the better understanding of the macrofaunal dynamic.

The region where this study was realized is currently on focus of a growing urban expansion, receiving lots of tourists every year. The Unamar beach particularly is under morphodynamic disequilibrium of the beach - shoreface system due to erosive trend, which indicates a potential risk for many of the coastline buildings, not to mention the fauna. Therefore, management actions and preservation should be taken in account in order to protect the local biodiversity at Unamar and Rasa beach.

\section{REFERENCES}

Amaral, A.C.Z. ; Rizzo, A.E. \& Arruda, E.P. 2011. Comunidades bentônicas de ambientes entremarés de praias arenosas. In: Amaral, A.C.Z.; Nallin, S.A.H. (Org.). Biodiversidade e Ecossistemas Bentônicos Marinhos do Litoral Norte de São Paulo, Sudeste do Brasil.ed. Campinas (SP): UNICAMP/IB. 370-387pp.

Andrade, F. C.; Veloso,V.G. \& Ribeiro, R. J. M. 2010. Caracterização Morfodinâmica e Sedimentológica do semi - arco praial Barra de São João - Barra do Una, RJ. Revista Brasileira de Geomorfologia, 11: 75-84.

Barros, F.; Borzone, C.A. \& Rosso, S. 2001. Macrofauna of six beaches near Guaratuba bay, Southern Brazil. Brazilian Archives of Biology and Technology,97: 399-404.
Bentes, A.M.I.; Fernandez, G.B. \& Ribeiro, A.Y. 1997. Estudo da morfodinâmica de praias compreendidas entre saquarema e macaé. Oecologia brasiliensis, 3: $229-243$.

Borzone, C.A.; Melo, S.; Rezende, K; Vale, R \& Krul, R. 2003. Macrobenthic intertidal communities from wave to tide dominated beach environments: a case study in two Brazilian beaches. Journal of Coastal Research.35: 472-480.

Borzone, C.A.\& Souza, J.R.B. \& Soares, A.G. 1996. Morphodynamic influence on the structure of inter and subtidal macrofaunal communities of subtropical sandy beaches. Revista Chilena de Historia. Natural. 69: 565-577.

Borzone, C.A. \& Souza, J.R.B. 1997. Estrutura da macrofauna bentônica no supra, meso e infralitoral de uma praia arenosa do sul do Brasil. Oecologia Brasiliensis. 3: $197-212$.

Brazeiro, A. 2001.Relationship between species richness and morphodynamics in sandy beaches: what are the underlying factors? Marine Ecology Progress Series. 224: $35-44$.

Brown, A. C. \& Mclachlan, A. 1990.Ecology of Sandy Shores.Elsevier, Amsterdan, 328p.

Capper, L.A. 2011. Dinâmica populacional de Talorchestiatucurauna (Muller, 1894) (Amphipoda, Talitridae) na praia Rasa - Município de Armação de Búzios, RJ. Universidade Santa Úrsula - USU. $80 \mathrm{p}$.

Conceição, M.; Manzatto, C.V.; Araújo, W.S.; Martin Neto, L.; Saab, S.C.;Cunha, T.J.F. \& Freixo, A.A. 1999. Estudo Comparativo De Métodos de Determinação Do Teor de Matéria Orgânica em Organossolos. Embrapa Solos. 2:1- 4.

Caron, E. \& Ribeiro-Costa, C.S. 2007. Bledius Leach from southern Brazil (Coleoptera, Staphylinidae, Oxytelinae). Revista Brasileira de Entomologia, 51(4): $452-457$.

Colombini, I. \& Chelazzi, L. 2003.Influence of marine allochthonous input on sandy beach communities. Oceanography and Marine Biology: an Annual Review,41: 115-159.

Dean, R.G. 1973. Heuristic models of sand transport in the surf zone. Proccedings of conference on engineering dynamics in the surf zone, 7: 208 -214 .

Defeo, O.; Brazeiro, A. ; De Alava, A. \& Riestra, G. 1997. Is sandy beach macrofauna only physically controlled? Role of substrate and competition in isopods. Estuarine coastal and shelf science. 45 : $453-462$.

Defeo, O.; Gómez, J.\& Lercari. D. 2001. Testing the swash exclusion hypothesis in sandy beaches populations: the crab mole Emerita brasiliensis in 
Uruguay. Marine Ecology Progress Series. 212: 159-170.

Defeo, O. \& McLachlan, A. 2005. Patterns, processes and regulatory mechanisms in sandy beach macrofauna: a multi - scale analysis. Marine ecology progress series. 295: $1-20$.

Dugan, J. E. ;Hubbard, D. M. ; Mccrary, M. D. \&Pierson, M. O. 2003. The response of macrofauna communities and shorebirds to macrophyte wrack subsidies on exposed sandy beaches of southern California. Estuarine, Coastal and Shelf Science. 58: 25-40.

Emery, K.O. 1961.A simple method of measuring beach profiles. Limnology and Oceanography.6: 90-93.

Fanini, L.; Cantarini, C. M. \& Scapini, F. 2005. Relationship between the dynamics of two Talitrus saltator populations and the impacts of activities linked to tourism. Oceanologia. 47(1): 93-112.

Fernandes, R.S.R \& Soares - Gomes, A.B. 2006. Community structure of macrobenthos in two tropical Sandy beaches with different morphodynamic features, Rio de Janeiro, Brazil. Marine Ecology. 27: 160-169.

Fernandez, G. B. 1998. Caracterização morfodinâmica do prisma praial, sob influência de sedimentos fluviais, no embaiamento Rio das Ostras - Cabo Búzios. Tese de Mestrado. Universidade Federal Fluminense - UFF. 81p.

Fernandez, G.B. \& MUEHE, D. 1998. A influência de sedimentos fluviais na morfologia da praia e antepraia no embaiamento Rio das Ostras - cabo Búzios, RJ. Revista Geosul.1: 1-6.

Figueiredo, S.A. \& Calliari, L.J. 2006. Sedimentologia e suas Implicações na Morfodinâmica das Praias Adjacentes às Desembocaduras da Linha de Costa do Rio Grande do Sul. Gravel, 4:73 - 87.

Jaramillo, E. 1994.Patterns of species richness in sandy beaches of South America. South African Journal of Zoology. 29(4): 221 - 234.

Jaramillo, E.; Contreras, H.; Duarte, C. \& Quijon, P. 2001. Relationships between community structure of the intertidal macroinfauna and sandy beaches characteristics along the Chilean coast. Marine Ecology. 22(4): $323-342$.

Jaramillo, E. \& McLachlan, A. 1993.Community and population responses of the macroinfauna to physical factors over a range of exposed sandy beaches in South - central Chile. Estuarine, Coastal and Shelf Science. 37: 615-624.

Lastra, M.; De La Huz, R.; Sánchez - Mata, A.G. ; Rodil, I.F.; Aerts, K.; Beloso, S. \& López, J. 2006 Ecology of exposeed Sandy beaches in northern Spain: Environmental factors controlling macrofauna communities. Journal of Sea Research. 55: 128 $-140$.

Lepka, D. L. 2008. Macrofauna de praias arenosas com diferentes graus de morfodinamismo no parque estadual da Ilha do Cardoso, SP, Brasil. Tese de Mestrado. Universidade Federal do Paraná - UFPR. 75p.

Llewellyn, P. J. \& Shackley, S. E. 1996. The effects of mechanical beach-cleaning on invertebrate populations. British Wildlife, 7:147-155.

Loureiro, V.F. 2006. Caracterização Espaço temporal da macrofauna de quatro praias arenosas situadas na Baía de Sepetiba, Rio de Janeiro, Brasil. Tese de Mestrado. Universidade Federal Fluminense - UFF. $41 p$.

Martins, A.L. G. 2007. A macrofauna bentónica das praias arenosas expostas do parque nacional de Superagui - PR: Subsidio ao plano de manejo. Tese de Mestrado. Universidade Federal do Paraná - UFPR. 77p.

Masalu, D.C.P. 2002. Coastal erosion and its social and environmental aspects in Tanzania: a case study in illegal sand mining. Coastal Management.30: $347-359$.

McLachlan, A. 1990. Dissipative beaches and macrofauna communities on exposed intertidal sands. Journal of Coastal Research.6: 57-71.

McLachlan, A. 2001.Coastal Beach ecosystems. In:Lewin (ed) Encyclopedia of Biodiversity. Academic Press, New York. 741-751pp.

McArdle, S.B.; McLachlan, A. 1992. Sand beach ecology: swash features relevant to the macrofauna. Journal of Coastal Research.8 (2): 398-407.

McLachlan, A.; Jaramillo, E; Donn, T.E. \& Wessels, F. 1993. Sandy beach macrofauna communities and their control by the physical environment: a geographical comparison. Journal of Coastal Research.15 (special issue):27-38.

McLachlan, A. \& Dorvlo, A. 2005.Global patterns in sandy beach macrobenthic communities. Journal of Coastal Research. 21: 674-687.

Mohriak, W. U. \& Barros, A.Z., 1990.Novas evidências de tectonismo cenozóico na região sudeste do Brasil: o graben de Barra de São João na plataforma continental de Cabo Frio, Rio de Janeiro. Revista Brasileira de Geociências.20: $187-196$.

Muehe, D.1996. Geomorfologia Costeira. In:Cunha,S.B. \& Guerra,A.J.T. (Orgs). Geomorfologia: Exercícios, técnicas e aplicações. Rio de Janeiro. Editora Bertrand Brasil. 191 - 238p.

Muehe, D.1998. Olitoral do Brasil e sua compartimentação. IN: Geomorfologia do Brasil. ORG. Guerra, A. J.T\&Cunha, S.B. Ed.. Bertrand Brasil, Rio de Janeiro.274 - 349pp. 
Muehe, D. ; Lima, C. F. \& Lins - de - Barros, F. M. 2006. Rio de Janeiro. In: MUEHE,D.. Erosão e Progradação do litoral brasileiro. Brasília: Ministério do Meio Ambiente. 265 - 296 pp.

Neves, F.M. \& Bemvenuti,C.E. 2006. Spatial distribution of macrobenthic fauna on three sandy beaches from northern Rio Grande do Sul, Southern Brazil. Brazilian Journal of Oceanography.54(2): 135-145.

Rodrigues, S.A. \&Shimizu, R.M. 1997. Autoecologia de callichirus major (say 1818). Oecologia brasiliensis.3: $155-170$.

Rodil, I.F.; Lastra, M.\& Lopez, J. 2007. Macroinfauna community structure and biochemical composition of sedimentary organic matter along a gradient of wave exposure in sandy beaches(NW Spain). Hydrobiologia.579: $301-316$.

Rosa, L.C.; Aluizio, R. \& Borzone, C.A. 2007. Talitridae (Amphipoda, Crustacea) das praias estuarinas da Baía de Paranaguá, Paraná, Brasil. Brazilian Journal of Aquatic Science and Technology. 11: $37-41$.

Schlacher, T. A. ; Schoeman, D. S. ; Dugan, J. ; Lastra, M. ; Jones, J. ; Scapini, F. \& Mclachlan, A. 2008. Sandy Beach ecosystems: key features, sampling issues, management challenges and climate change impacts. Marine Ecology, 29: 70-90.

Serejo, C. S. 2004. Talitridae(Amphipoda, Gammaridae) from the Brazilian coastline. Zootaxa. 646: 1 - 29.

Simão, D.S.; Ramos, M.F. \&Soares - Gomes, A. 2006. Population structure of callichirus major (say 1818) (crustacea: thalassinidea) in sandy beach of Rio de Janeiro state, southeast brazil coast. Journal of Coastal Research. 39: 1165 - 1168.
Short, A.D. 1996. The role of wave height, period, slope, tide range and embayament in beach classification: a review. Revista chilena de historia natural. 69: $589-604$.

Short, A.D. 1999. Handbook of beach and shoreface morphodynamics. John Wileyand Sons Ltd. Austrália, 491p.

Short, A.D. \& Wright, L.D. 1983. Physical variability of sandy beaches. In Mclachlan, A. \& Erasmus, T (eds.). Sandy beaches as ecosystems. Netherland: W. Junk Publishers. $133-144 p p$.

Souza, J.R.B \& Gianuca, N.M. 1995.Zonation and seazonal variation of the intertidalmacrofauna on a sandy beach of Paraná State, Brazil. Scientia Marina. 59(2): 103 - 111.

Suguio, K. 1973. Introdução à sedimentologia. São Paulo: Edgard Blucher. 317p.

Veloso, V.G.; Caetano, C.H.S. \& Cardoso. 2003. Composition, structure and zonation of intertidal macrofauna in relation to physical factors in microtidal sandy beaches at Rio de Janeiro State, Brazil. Scientia Marina, 67: 393-402.

Veloso, V.G. \& Cardoso, R.S. 2001.The effects of morphodynamics on the spatial and temporal variation of the macrofauna of thre sandy beaches on the Rio de Janeiro state, Brazil. Journal of Marine Biology Association in UK. 81: 369-375.

Veloso, V.G.; Silva, E.S.; Caetano,C.H.S. \& Cardoso, R.S. 2006. Comparison between the macrofauna of urbanized and protected beaches in Rio de Janeiro state, Brazil. Biological Conservation, 127: 510-515.

Submetido: Abril/2013 Revisado: Março/2016 Aceito: Abril/2016 